\title{
Severe hemophilia A
}

INSERM

\section{Source}

INSERM. (1999). Orphanet: an online rare disease and orphan drug data base. Severe hemophilia A. ORPHA:169802

Severe hemophilia A is a form of hemophilia A (see this term) characterized by a large deficiency of factor VIII leading to frequent spontaneous hemorrhage and abnormal bleeding as a result of minor injuries, or following surgery or tooth extraction. 